\title{
Nutritional value of tiger nut (Cyperus esculentus) offal on the performance of broiler chickens
}

* Alu, S. E., Oseze, F. S. and Ogoshi, E. J. Department of Animal Science, Faculty of Agriculture,

Nasarawa State University, Keffi, P.M.B.135, Shabu-Lafia campus, Nasarawa State, Nigeria.

Corresponding author: drsamalu@nsuk.edu.ng; +2348033690937

\begin{abstract}
Tiger nut offal is one of the common agro by products available in appreciable quantity all yaer round especially within the northern part of Nigeria. Its nutritional value is somewhat close to those of maize offal. Therefore, a 56 - day experiment was conducted to evaluate the response of broiler chickens fed graded levels of Tiger nut offal (TNO) as an energy source. Five iso-nitrogenous and iso-caloric diets tagged T1, T2, T3, T4 and T5, were compounded to contain 23 and 20\% crude protein and 2800 and $3000 \mathrm{kcal} / \mathrm{kg}$ of metabolizable energy for starter and finisher phases, respectively. The TNO was included at 0, 5, 10, 15 and 20\% levels in treatments, respectively such that T1 served as the control diet. A total of 200, one day old chicks were allotted to the 5 treatment groups, replicated 4 times and each replicate was allotted 10 birds. Parameters evaluated included growth rate, economics of production, blood parameters and carcass characteristics. The results showed that there was no significant variation $(P>0.05)$ in the values obtained for growth parameters, economics of production, haematological parameters and serum biochemistry. However, there was significant difference $(P<0.05)$ in dressed weight $(1155.00 \mathrm{vs} .1350 .00$ vs. $1350.00 \mathrm{vs}$. 1525.00 and $1530.00 \mathrm{gbird}^{-1}$ ) and shanks weight (59.50 vs. $100.00 \mathrm{vs.} 67.00 \mathrm{vs.} 85.00$ and 60.00 gbird $^{-1}$ ) which increased across the treatments as the levels of inclusion of TNO increased in the diets. Birds fed the diets 15 (T4) and 20\% (T5) gave the best results compared to those fed the control and other levels. From the results of this experiment, poultry farmer can use up to $20 \%$ of TNO as a replacement for conventional energy source in the diet of broiler chickens without compromising the meat quality and health status of the birds.
\end{abstract}

Keywords: Broiler chickens, energy source, nutritional value, performance, tiger nut offal

\section{Introduction}

The use of unconventional feed stuffs as substitutes for grains and other feedstuffs have been suggested thus, the search for non-conventional feedstuffs has been the most active area of animal nutrition research in the tropical world (Ikani and Adesehinwa, 2000). The search for cheaper sources of animal protein brings poultry birds into focus. Yakubu et al. (2010) suggested that the quickest potential for bridging protein supply - demand gap lies in the production of highly prolific animals that are efficient converters of feed to flesh, have short generation interval such as poultry birds and the integration of the wide array of cheap and locally available nonconventional feedstuffs at our disposal into well-defined feeding systems to reduce cost. Tiger nut (Cyperus esculentus) is one of the underutilized crops of the family Cyperaceae, which produces rhizomes from the base and tubers that are somewhat spherical. According to Sanchez-Zapata et al. (2012), tiger nut is an edible perennial grass-like plant, native to the 'old world' which consists of Europe, Asia and Africa and is a lesser-known vegetable that produces sweet nut-like tubers known as 'earth almond'. It is often cultivated for its 


\section{Nutritional value of tiger nut (Cyperus esculentus) offal}

nutritive edible nuts and high content of soluble glucose of about 21\% (Bamishaiye et al., 2010). Nutritionally, the nut produces high quality oil of up to about $25.5 \%$ content and about $8 \%$ of protein. The nut is high in oil content and is valued for the nutritious starch content, dietary fibre and carbohydrates (Bibek, 2001). Tiger-nut is also an excellent source of some useful minerals such as iron and calcium which are essential for body growth and development (Oladele and Aina, 2007). They also contain other mineral elements such as phosphorus, potassium sodium, magnesium, zinc and traces of copper and vitamins $\mathrm{E}$ and $\mathrm{C}$ (Oladele and Aina, 2007). It was reported that tiger-nut is high in dietary fiber content, which could be effective in the treatment and prevention of many diseases including colon cancer, coronary heart diseases, obesity, diabetics and gastro intestinal disorders while its tubers are used as an aphrodisiac, carminative, diuretic and a stimulant (Aletor et al., 1995). Tiger-nuts have been reported to be used in the treatment of flatulence, indigestion, diarrhoea and dysentery. In addition, tigernut has been demonstrated to contain higher essential amino acids than those proposed in the protein standard by the FAO/WHO in 1985 for satisfying adult needs (Belewu and Adedunmi, 2008). In spite of the numerous health benefits of tiger nut, its potentials and prospects as energy source for poultry and livestock production has not been delved into extensively (Oladele et al., 2010). It is against this backdrop that this study was carried out to investigate the prospect of feeding graded levels of tiger nut offal to the diets of broiler birds as a source of energy and the economic implications.

\section{Materials and methods \\ Study area}

The experiment was carried out at the Research and Teaching Farm of the Faculty of Agriculture, Nasarawa State University, Keffi, Shabu - Lafia Campus. It is located in the guinea savanna zone of North Central Nigeria. It is found in latitude $08^{\circ} 35^{\prime} \mathrm{N}$ and longitude $08^{\circ} 33^{\prime} \mathrm{E}$. the mean monthly maximum and minimum temperatures are 35. $06^{\circ} \mathrm{C}$ respectively while the mean monthly relative humidity is $74 \%$. The rainfall is about 168. $90 \mathrm{~mm}$ (NIMET, 2008).

\section{Laboratory analyses of TNO}

Proximate analyses of TNO was carried out in the Laboratory of the Department of Animal Science, Faculty of Agriculture, Nasarawa State University, Keffi, ShabuLafia campus, using the procedure outlined by AOAC (2000). The result of the proximate analysis is presented in Table 3.

\section{Feed description and experimental design}

Five diets tagged T1, T2, T3, T4 and T5 were compounded to be isocaloric ( 2800 and $3000 \mathrm{kcal} / \mathrm{kg}, \mathrm{ME}$ ) and isonitrogenous (23 and $20 \%$ crude protein) using tiger nut offal for starter and finisher birds, respectively. The TNO was included in the diets at $0,5,10,15$ and $20 \%$ for the respective treatments in a Completely Randomized Design (CRD) for both starter and finisher phases; the diets were compounded such that they meet the nutrient requirements of those classes of birds as described by Oluyemi et al. (2002). The gross and energy composition of the experimental diets for starter and finisher birds are presented in Tables 2 and 3 .

Experimental birds, management and design

A total of 200 day-old Anak 2000 broiler chicks were used for the experiment. They were randomly allocated to the diets at the rate of 10 birds per replicate and each treatment was replicated four times in a Completely Randomized Design. All experimental birds were given feed and water ad - libitum and standard management practices such as daily 


\section{Alu, Oseze and Ogoshi}

routines and vaccinations were strictly followed as described by Oluyemi and Robert (2002). The birds were housed in 20 deep litter pens with wood shavings spread on cemented floor to the depth of 2-5 cm. The wood shavings were raked weekly to ensure aeration and clean litter throughout the study. The total floor space of the pen was $24 \mathrm{~m}^{2}$ and the space per bird was 0.12 $\mathrm{m}^{2}$.

\section{Vaccination and medication schedule}

A planned programme of vaccination was followed strictly. The birds were vaccinated against Newcastle and Gumboro diseases. Procedure for vaccination was as recommended by the Jos ECWA Veterinary Services Department and the doses were administered according to the manufacturer's specification. Prophylactic measures were observed to prevent any possible outbreak of diseases.

\section{Data collection}

\section{Growth parameters}

Birds were batch weighed with digital weighing balance at the beginning of the experiment and weekly thereafter. Feeds were adjusted according to the new body weight changes. Other biological evaluations such as feed intake, body weight gain were recorded on replicate basis. Feed conversion ratio (FCR) was computed according to Mcdonald et al. (1995). Other parameters determined included final live weight, protein consumed and protein efficiency ratio.

Table 1: Gross composition of starter experimental diets

\begin{tabular}{llllll}
\hline Ingredients & T1 (0\%) & T2 (5\%) & T3 (10\%) & T4 (15\%) & T5 (20\%) \\
\hline Full fat Soybean & 19.22 & 19.22 & 19.22 & 19.22 & 20.22 \\
Groundnut cake & 22.76 & 22.76 & 22.76 & 22.76 & 22.76 \\
Rice bran & 22.00 & 19.02 & 19.02 & 19.02 & 13.02 \\
Tiger nut offal & 0.00 & 5.00 & 10.00 & 15.00 & 20.00 \\
Maize & 30.52 & 19.00 & 25.00 & 19.00 & 19.00 \\
**Premix & 0.25 & 0.25 & 0.25 & 0.25 & 0.25 \\
Salt & 0.25 & 0.25 & 0.25 & 0.25 & 0.25 \\
Bone ash & 2.50 & 1.00 & 1.00 & 1.00 & 1.00 \\
Palm oil & 2.00 & 3.00 & 2.00 & 3.00 & 3.00 \\
Methionine & 0.25 & 0.25 & 0.25 & 0.25 & 0.25 \\
Lysine & 0.25 & 0.25 & 0.25 & 0.25 & 0.25 \\
Total & 100.00 & 100.00 & 100.00 & 100.00 & 100.00 \\
Calculate energy and chemical composition & & & \\
*Energy (kcal/kg, ME) & 2837.45 & 2802.10 & 2814.66 & 2802.10 & 28.33 .10 \\
Crude protein (\%) & 23.12 & 23.00 & 23.10 & 23.00 & 23.03 \\
Crude fibre (\%) & 5.29 & 5.52 & 5.38 & 5.52 & 5.15 \\
Ether extract (\%) & 12.04 & 12.65 & 11.73 & 12.65 & 12.11 \\
Ash (\%) & 4.74 & 4.95 & 4.81 & 4.96 & 4.62 \\
Calcium (\%) & 1.13 & 0.65 & 0.59 & 0.65 & 0.65 \\
Phosphorus (\%) & 1.15 & 0.82 & 0.83 & 0.82 & 0.71 \\
Lysine (\%) & 1.29 & 1.28 & 1.27 & 1.25 & 1.25 \\
Methionine (\%) & 0.57 & 0.57 & 0.55 & 0.54 & 0.54 \\
\hline "Calure
\end{tabular}

*Calculated from Pauzenga (1985), **The vitamin - mineral premix supplied the following per 100kg of diet: Vitamin A 15,000 I.U, Vitamin D 3 300,000 I.U., Vitamin E 3,000 I.U., Vitamin K 2.50mg, Thiamin,

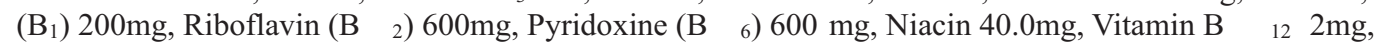
Pantothenic acid 10.0mg, Folic acid, 100mg, Biotin 8mg, Choline chloride 50g, Anti -oxidant $12.5 \mathrm{~g}$, Manganese 96g, Zinc 6g, Iron 24g, Copper 0.6g, Iodine 0.14g, Selenium 24mg, Cobalt 214mg. 
Nutritional value of tiger nut (Cyperus esculentus) offal

Table 2: Gross composition of finisher experimental diets

\begin{tabular}{|c|c|c|c|c|c|}
\hline Ingredients & T1 (0\%) & T2 (5\%) & T3 (10\%) & T4 (15\%) & T5 (20\%) \\
\hline Full fat Soybean & 20.00 & 20.00 & 20.00 & 20.00 & 20.00 \\
\hline Groundnut cake & 15.00 & 15.00 & 15.50 & 15.50 & 16.50 \\
\hline Rice bran & 16.00 & 16.00 & 12.50 & 7.00 & 1.50 \\
\hline Tiger nut offal & 0.00 & 5.00 & 10.00 & 15.00 & 20.00 \\
\hline Maize & 42.00 & 39.50 & 38.00 & 38.00 & 38.00 \\
\hline$* *$ Premix & 0.25 & 0.25 & 0.25 & 0.25 & 0.25 \\
\hline Salt & 0.25 & 0.25 & 0.25 & 0.25 & 0.25 \\
\hline Bone ash & 3.00 & 1.00 & 1.00 & 1.00 & 1.00 \\
\hline Palm oil & 3.00 & 2.50 & 2.50 & 2.50 & 2.00 \\
\hline Methionine & 0.25 & 0.25 & 0.25 & 0.25 & 0.25 \\
\hline Lysine & 0.25 & 0.25 & 0.25 & 0.25 & 0.25 \\
\hline Total & 100.00 & 100.00 & 100.00 & 100.00 & 100.00 \\
\hline \multicolumn{6}{|c|}{ Calculate energy and chemical composition } \\
\hline *Energy $(\mathrm{kcal} / \mathrm{kg}, \mathrm{ME})$ & 3029.18 & 3013.98 & 3007.80 & 3027.91 & 3019.74 \\
\hline Crude protein $(\%)$ & 20.17 & 20.37 & 20.22 & 20.15 & 20.32 \\
\hline Crude fibre $(\%)$ & 4.63 & 4.86 & 4.69 & 4.35 & 4.03 \\
\hline Ether extract (\%) & 12.02 & 11.60 & 11.19 & 10.59 & 9.54 \\
\hline Ash $(\%)$ & 3.90 & 4.08 & 3.94 & 3.64 & 3.36 \\
\hline Calcium (\%) & 1.36 & 0.61 & 0.61 & 0.60 & 0.57 \\
\hline Phosphorus (\%) & 1.12 & 0.78 & 0.71 & 0.62 & 0.52 \\
\hline Lysine (\%) & 1.18 & 1.78 & 1.15 & 1.13 & 1.12 \\
\hline Methionine $(\%)$ & 0.55 & 0.55 & 0.53 & 0.52 & 0.51 \\
\hline \multicolumn{6}{|c|}{ 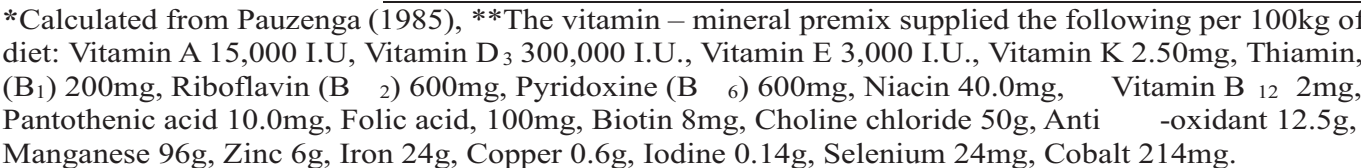 } \\
\hline
\end{tabular}

\section{Economics of production}

Parameters such as cost of feed per unit weight gain, profit, cost of production, revenue and gross margin were determined.

\section{Carcass characteristics}

At the end of the $8^{\text {th }}$ week of experimentation, carcass data was collected from four randomly selected birds per treatment group. The birds were fasted for $12 \mathrm{~h}$ (but with access to water only) and individually weighed using a 5-kg scale with a precision of 0.005 . The birds were starved to determine the actual live weight of the birds and reduce gut content thus, reducing the risk of contamination of the carcass during dressing without affecting meat quality. They were then slaughtered by severing the carotid arteries and jugular veins and blood drained under gravity; the carcasses were then divided into the following parts as described by Kleczek et al. (2007).

Head-The head was obtained by cutting off between the occipital condyl and the atlas.

Neck-This was obtained by cutting along the line joining the cephalic borders of the coracoids.

Shank-This was obtained by cutting off through the hock-joint (sesmoid).

Wing-The wing was obtained by cutting through the shoulder joint.

Thigh-This was obtained by cutting through the hip joint (from the pubic process, through the groin towards the back, and the along the backbone, starting from the anterior border of the pelvis).

Breast plate-It was obtained by a double cut through the cartilaginous junctures of the ribs, from the anterior border of the backbone towards the coracoids. 


\section{Alu, Oseze and Ogoshi}

Back-This is referred to as the dorsallumbar quarter (the remaining part of the carcass). The relative fasted body weight (\% of final live body weight) was obtained. The weight of the thigh, breast, and back were taken as the carcass weight, which was later expressed as percentage of the final live body weight. Similarly, the relative weights of the cut parts (head, neck, shank, wing, thigh, breast, and back) and the visceral organs (liver, heart, kidney, gizzard and small and large intestines), was determined using the formula (Mohammed et al., 2008; Grosso et al., 2009):

Relative weight (cut part or organ) $=$ Fresh weight of cut part or organ X100

Final live body weight of bird

\section{Haematological indices}

At the end of the feeding trial of the finisher phase, blood samples were collected for the evaluation of the haematological indices. The bloods were collected into sample bottles containing $1 \mathrm{mg}$ of dipotassium salts of ethylene diamine tetra acetic acid $\left(\right.$ EDTA-K $^{2}$ ) to $1 \mathrm{ml}$ of blood. The haematological indices determined were packed cell volume (PCV), red blood cell count (RBC), white blood cell count (WBC) and haemoglobin concentration. PCV was determined using wintrobes micro haematocrit method (Margi, 1997); haemoglobin concentration was determined by the Cyanomethaemoglobin method as outlined by Kelly (1979). The improved Neubarhaemocytometer method as described by Jain (1986) was used to estimate the red and white blood cells. Mean corpuscular volume (MCV), mean corpuscular haemoglobin $(\mathrm{MCH})$ and mean corpuscular haemoglobin concentration (MCHC) were computed according to Jain
(1986).

Serum biochemical constituents

Another blood samples were collected in another separate sample bottles without anti-coagulant to allow clotting for serum biochemical analysis. Constituents such as protein, globulin, urea and triglyceride were analyzed using sigma kits while glucose was analyzed according to Schalm etal. (1975).

\section{Statistical analysis}

Data obtained were subjected to One Way Analysis of Variance (ANOVA). The separation of the means was effected using least significance difference method and tested at probability level of $5 \%$ as described by Steel and Torries (1980). Each experimental bird was randomly assigned to a test diet in a Completely Randomized Design (CRD). The following statistical mode was used: $Y_{i j}=\mu+T_{i j}+e_{i j}$ Where $Y_{i j}=$ Individual observation $\mu=$ Population mean, $\mathrm{T}_{\mathrm{ij}}=$ Treatment error, $\mathrm{e}_{\mathrm{ij}}=$ Random error.

\section{Results and discussion \\ Proximate composition of TNO}

The results of the proximate composition of TNO reveal that the test ingredient is rich in energy (2229.78 kcal/kg, ME) and carbohydrate $(51.82 \%)$ but low in other nutrients such as crude protein $(8.57 \%)$, crude fibre $(5.96 \%)$, ash $(4.43 \%)$ and NFE $(45.86 \%)$. The relatively low moisture content $(3.65 \%)$ of the TNO indicates that the material may have a high keeping quality over a long period of time without spoilage. In view of the high energy and carbohydrate values that are somewhat close to most cereal grains (Alu, 2015b), it suggests that TNO could conveniently replace other conventional energy feedingstuffs in the diets of broiler chickens. 


\section{Nutritional value of tiger nut (Cyperus esculentus) offal}

Table 3: Proximate and energy composition of TNO

\begin{tabular}{llllllll}
\hline $\begin{array}{l}* \text { Energy } \\
(\mathbf{k c a l} / \mathbf{k g}, \mathbf{M E})\end{array}$ & $\mathbf{C P}(\boldsymbol{\%})$ & $\begin{array}{l}\text { CF } \\
(\%)\end{array}$ & $\begin{array}{l}\text { EE } \\
(\%)\end{array}$ & $\begin{array}{l}\text { Ash } \\
(\%)\end{array}$ & $\begin{array}{l}\text { CHO } \\
(\%)\end{array}$ & $\begin{array}{l}\text { NFE } \\
(\%)\end{array}$ & $\begin{array}{l}\text { Moisture } \\
(\%)\end{array}$ \\
\hline 2229.78 & 8.57 & 5.96 & 3.51 & 4.43 & 51.82 & 45.86 & 3.65 \\
\hline
\end{tabular}

*Calculated from Pauzenga (1985)

\section{Effect of graded levels of TNO on the} growth performance of broiler chicks

The results of the effect of graded levels of TNO on the growth performance of broiler chicks are presented on Table 4. There was no significant variation $(\mathrm{P}>0.05)$ on all the parameters evaluated. However, numerical differences existed indicating an upward trend for final weight ( $960.00 \mathrm{vs.} 992.00 \mathrm{vs.}$ 975.00 vs. 1000.00 and 870.00 gbird $^{-1}$ ) and daily weight gain (31.00 vs. 32.50 vs. 31.25 vs. 32.10 and 27.50 gbird $^{-1}$ ) as the level of TNO inclusion increased from the control diet to T4 (15\%). The mortality rates, 7.50 vs. 15.00 vs. 10.00 vs. 15.00 and $2.50 \%$ recorded for T1, T2, T3, T4 and T5 were due to other challenges such as health and mishaps as there was no nutritional disorder. The non-significant difference observed may be seen as an indication of the safety and adequacy of the test ingredient (Alu et al., 2009). Birds would normally respond to bad diets almost immediately after consumption by having poor turnover of feed to flesh and more importantly, depressed feed intake. The values recorded in the present study for final body weight, daily weight gain and FCR were close to those previously reported by Agbabiaka et al. (2012), Agbabiaka et al. (2013), Kwadwo et al. (2014) and Agbabiaka et al. (2013).

Table 4: Effect of graded levels of TNO on growth performance of broiler chicks

\begin{tabular}{|c|c|c|c|c|c|c|c|}
\hline \multirow[t]{2}{*}{ Parameters } & \multicolumn{7}{|c|}{ TREATMENTS } \\
\hline & $\begin{array}{l}\text { T1 } \\
(0 \%)\end{array}$ & $\begin{array}{l}\text { T2 } \\
(5 \%)\end{array}$ & $\begin{array}{l}\text { T3 } \\
(10 \%)\end{array}$ & $\begin{array}{l}\text { T4 } \\
(15 \%)\end{array}$ & $\begin{array}{l}\text { T5 } \\
(20 \%)\end{array}$ & SEM & LOS \\
\hline Initial weight (g/bird) & 94.50 & 81.50 & 94.50 & 96.50 & 101.00 & 7.36 & NS \\
\hline Final weight ( $\mathrm{g}$ /bird) & 960.00 & 992.00 & 975.00 & 1000.00 & 870.00 & 20.77 & NS \\
\hline Feed intake (g/bird) & 55.50 & 55.50 & 51.50 & 53.50 & 48.00 & 1.67 & NS \\
\hline Weight gain ( $\mathrm{g} /$ bird) & 31.00 & 32.50 & 31.25 & 32.10 & 27.50 & 0.68 & NS \\
\hline FCR & 2.42 & 2.59 & 2.72 & 3.285 & 5.24 & 0.52 & NS \\
\hline Protein Intake (g/bird) & 13.00 & 13.00 & 12.10 & 12.00 & 11.20 & 0.35 & NS \\
\hline PER & 2.65 & 2.50 & 2.50 & 2.70 & 2.50 & 0.15 & NS \\
\hline Mortality (\%) & 7.50 & 15.00 & 10.00 & 15.00 & 2.50 & 2.11 & NS \\
\hline
\end{tabular}

$\mathrm{SEM}=$ Standard error of mean, $\mathrm{LOS}=$ Level of Significance, $\mathrm{NS}=$ Not significantly different $(\mathrm{P}>0.05)$.

\section{Effect of graded levels of TNO on the economics of production of broiler chicks}

A similar trend was recorded for the economic implication (Table 5). There was no variation $(\mathrm{P}>0.05)$ on the parameters evaluated due to TNO inclusion across the treatment groups. However, there was a numerical reduction in the cost of production (465.50 vs. 466.50 vs. 433.00 vs. 427.40 and $406.00<$ ) for treatments $\mathrm{T} 1$ to $\mathrm{T} 5$, respectively, while that of profit (1933.00 vs. 1933.50 vs. 1092.50 vs. 1972.60 and $1994.00<$ ) increased as the level of TNO increased in the diets. The reduction in the cost of production and increase in profit are attributed to the fact that the test ingredient did not attract any monetary value as it is considered as a waste product (Adgizi et al., 2013) after local drinks production. 
Alu, Oseze and Ogoshi

Table 5: Economics of production of broiler chicks fed graded levels of TNO

\begin{tabular}{|c|c|c|c|c|c|c|c|}
\hline \multirow[t]{2}{*}{ Parameters } & \multicolumn{7}{|c|}{ TREATMENTS } \\
\hline & $\begin{array}{l}\text { T1 } \\
(0 \%)\end{array}$ & $\begin{array}{l}\text { T2 } \\
(5 \%)\end{array}$ & T3 (10\%) & T4 (15\%) & $\begin{array}{l}\text { T5 } \\
(20 \%)\end{array}$ & SEM & LOS \\
\hline Feed cost $/ 100 \mathrm{~kg}(</ \mathrm{kg})$ & 17045.50 & 17039.10 & 16039.10 & 15189.10 & 15409.10 & - & - \\
\hline Feed cost $/ \mathrm{kg}(</ \mathrm{kg})$ & 170.45 & 170.39 & 160.39 & 151.89 & 154.09 & - & - \\
\hline $\mathrm{FC} / \mathrm{WG}(</ \mathrm{kg})$ & 3.50 & 5.45 & 4.50 & 3.50 & 3.50 & 1.91 & NS \\
\hline Cost of production $(<)$ & 465.50 & 466.50 & 433.0 & 427.40 & 406.0 & 9.71 & NS \\
\hline Profit $(<)$ & 1933.00 & 1933.50 & 1092.50 & 1972.60 & 1994.00 & 271.53 & NS \\
\hline Revenue (<) & 74.50 & 78.50 & 75.50 & 77.50 & 66.15 & 1.71 & NS \\
\hline Gross margin $(<)$ & 390.95 & 388.00 & 357.50 & 349.50 & 340.00 & 8.77 & NS \\
\hline
\end{tabular}

\section{Effect of graded levels of TNO on the} growth performance of broiler finisher chickens

Table 6 summarizes the effect of graded levels of TNO on growth parameters of broiler finisher chickens. Although there was no significant variation $(\mathrm{P}>0.05)$ in all the parameters, final weight, weight gain, protein intake and PER decreased numerically whereas feed intake and FCR increased with increased in the level of inclusion of TNO in the diets. The results obtained in the present study were superior to those earlier reported by Agbabiaka et al. (2012). The authors reported $1350-1720$ $\operatorname{gbird}^{-1}, 18.57-39.52$ gbird $^{-1}$ and $3.37-6.28$ for final live weight, daily body weight gain and FCR, respectively. The superiority in the values recorded in the present may be attributed to the safety and high quality of the diets since the diets were balanced for all the nutrients required by this class of birds.

Table 6: Effect of graded levels of TNO on growth performance of broiler finisher chickens

\begin{tabular}{|c|c|c|c|c|c|c|c|}
\hline \multirow[t]{2}{*}{ Parameters } & \multicolumn{7}{|c|}{ TREATMENTS } \\
\hline & $\begin{array}{l}\text { T1 } \\
(0 \%)\end{array}$ & $\begin{array}{l}\text { T2 } \\
(5 \%)\end{array}$ & $\begin{array}{l}\text { T3 } \\
(10 \%)\end{array}$ & $\begin{array}{l}\text { T4 } \\
(15 \%)\end{array}$ & T5 (20\%) & SEM & LOS \\
\hline Initial weight (g/bird) & 960.00 & 992.00 & 975.00 & 1000.00 & 870.00 & 20.77 & NS \\
\hline Final weight(g/bird) & 1935.00 & 1635.00 & 1765.00 & 1865.00 & 1355.00 & 89.22 & NS \\
\hline Feed intake (g/bird) & 112.00 & 82.50 & 102.50 & 132.50 & 82.50 & 10.33 & NS \\
\hline Weight gain ( $\mathrm{g} / \mathrm{bird}$ ) & 46.50 & 30.50 & 37.40 & 41.05 & 23.50 & 3.80 & NS \\
\hline FCR & 2.00 & 2.50 & 3.00 & 3.00 & 5.50 & 0.57 & NS \\
\hline Protein Intake ( $\mathrm{g} / \mathrm{bird})$ & 22.50 & 16.550 & 20.90 & 26.50 & 16.50 & 2.07 & NS \\
\hline PER & 2.00 & 2.00 & 1.90 & 1.50 & 1.50 & 0.20 & NS \\
\hline Mortality (\%) & 5.00 & 7.50 & 20.00 & 2.50 & 16.00 & - & - \\
\hline
\end{tabular}

$\mathrm{SEM}=$ Standard error of mean, $\mathrm{LOS}=$ Level of Significance, $\mathrm{NS}=$ Not significantly different $(\mathrm{P}>0.05)$

Effect of graded levels of TNO on the economics of production of broiler finisher chickens

The economics of production of broiler finisher birds fed TNO (Table 7) showed a similar trend as in the starter phase. There was no significant variation $(\mathrm{P}>0.05)$ due to TNO inclusion on the parameters evaluated. However, feed cost/weight gain
(4.00 vs. 6.00 vs. 4.65 vs. 4.50 and $<5.85 / \mathrm{kg})$, profit $(975.50$ vs. 1886.00 vs. 1817.40 vs. 1702.75 and $<1889.50)$ and gross margin ( 538.50 vs. 440.00 vs. 492.50 vs. 598.60 vs. and <455.00) increased numerically with increase in the level of TNO in the diets. Cost of production and revenue reduced with increase the level of TNO in the feed. 


\section{Nutritional value of tiger nut (Cyperus esculentus) offal}

Table 7: Economics of production of broiler chickens fed graded levels of TNO

\begin{tabular}{llllllll}
\hline Parameters & \multicolumn{7}{c}{ TREATMENTS } \\
\cline { 2 - 8 } & $\begin{array}{l}\text { T1 } \\
(\mathbf{0 \% )}\end{array}$ & $\begin{array}{l}\text { T2 } \\
\mathbf{( 5 \% )}\end{array}$ & $\begin{array}{l}\text { T3 } \\
\mathbf{( 1 0 \% )}\end{array}$ & $\begin{array}{l}\text { T4 } \\
\mathbf{( 1 5 \% )}\end{array}$ & $\begin{array}{l}\text { T5 } \\
\mathbf{( 2 0 \% )}\end{array}$ & SEM & LOS \\
\hline Feed cost/100kg $(</ \mathrm{kg})$ & 191.05 & 181.30 & 178.13 & 178.60 & 178.08 & - & - \\
Feed cost/kg $(</ \mathrm{kg})$ & 191.05 & 181.30 & 178.13 & 178.60 & 178.08 & - & - \\
FC/WG $(</ \mathrm{kg})$ & 4.00 & 6.00 & 4.65 & 4.50 & 5.85 & 2.21 & $\mathrm{NS}$ \\
Cost of production $(<)$ & 650.0 & 514.0 & 582.60 & 697.250 & 510.50 & 39.45 & $\mathrm{NS}$ \\
Profit $(<)$ & 975.50 & 1886.00 & 1817.40 & 1702.75 & 1889.50 & 169.07 & $\mathrm{NS}$ \\
Revenue $(<)$ & 115.00 & 73.50 & 90.00 & 98.650 & 55.50 & 9.16 & $\mathrm{NS}$ \\
Gross margin $(<)$ & 538.50 & 440.00 & 492.50 & 598.60 & 455.00 & 33.25 & $\mathrm{NS}$ \\
\hline SEM St
\end{tabular}

$\mathrm{SEM}=$ Standard error of mean, $\mathrm{LOS}=$ Level of Significance, $\mathrm{NS}=$ Not significantly different $(\mathrm{P}>0.05), \mathrm{FC} / \mathrm{WG}=$

Feed cost/ weight gain.

\section{Effect of graded levels of TNO on carcass characteristics and visceral organs of broiler finisher chickens}

The results of the effect of graded levels of TNO on carcass characteristics and visceral organs of broiler finisher chickens are presented in Table 8 . The results show that there was no significant difference $(\mathrm{P}>0.05)$ in most of the parameters evaluated except for dressed weight (1155.00 vs. $1350.00 \mathrm{vs.}$ 1350.00 vs. 1525.00 and 1530.00 gbird $^{-1}$ ) and shanks weight (59.50 vs. 100.00 vs. 67.00 vs. 85.00 and 60.00 gbird $^{-1}$ ) which significantly $(\mathrm{P}<0.05)$ increased across the treatment groups as the levels of inclusion of TNO increased in the diets. Birds fed the diets 15 (T4) and 20\% (T5) gave the best results compared to those fed the control and other levels. There was numerical increase in the length of the small $(169.75$ vs. 185.00 vs. 176.50 vs. 202.50 and 181.50 $\left.\mathrm{cm} \mathrm{bird}^{-1}\right)$ and large intestines (12.00 vs. 13.50 vs. 13.50 vs. 14.50 and $13.75 \mathrm{~cm}$ bird $^{-}$ ${ }^{1}$ ), weight of full gizzard (42.00 vs. $95.00 \mathrm{vs.}$ 58.00 vs. 76.50 and 80.00 gbird $^{-1}$ ) and kidney ( 1.25 vs. 1.30 vs. 1.45 vs. 1.55 and $1.90 \mathrm{gbird}^{-1}$ ) as the level of TNO increased in the feeds. The results obtained in the present study confirms the earlier findings of Kwadwo et al. (2014) who fed broiler finisher chickens with alkaline-treated TNO and reported similar values for most of the carcass parameters. Alu (2015a) similar reported a non-significant variation in most of the carcass cuts and visceral organs of growing rabbits fed TNO baseddiets.

Effect of graded levels of TNO on haematological indices of broiler finisher chickens

There was no significant variation $(\mathrm{P}>0.05)$ in the values for haematological indices (Table 9) evaluated. However, leukocytes, erythrocytes, PCV and haemoglobin increased numerically with increase in TNO in the feeds. The values recorded in the present study fell within the normal range for healthy broiler finisher chickens (Jain, 1993). The haematological indices are a reflection of health status of an animal and this implies that the test ingredient was not deleterious to the well-being of the birds.

Effect of graded levels of TNO on serum biochemical constituents of broiler finisher chickens

Similar to the haematological indices, there was no significant difference $(\mathrm{P}>0.05)$ in all the values recorded for serum biochemical constituents (Table 10) across the treatment groups due to TNO inclusion in the diets. Values recorded for total protein (36.00 vs. 48.00 vs. 39.50 vs. 43.50 and $41.50 \mathrm{~g} / \mathrm{dL}$ ), glucose ( 1.25 vs. 1.55 vs. 1.80 vs. 1.55 and $1.75 \mathrm{mmol} / \mathrm{L})$, creatinine (37.50 vs. 37.50 vs. 39.50 vs. 44.00 and $42.50 \mathrm{mmol} / \mathrm{L}$ ) and 


\section{Alu, Oseze and Ogoshi}

Table 8: Effect of graded levels of TNO on the carcass characteristics of broiler finisher birds

\begin{tabular}{|c|c|c|c|c|c|c|c|}
\hline Parameters & T1 (0\%) & $\begin{array}{l}\text { T2 } \\
(5 \%)\end{array}$ & $\begin{array}{l}\text { T3 } \\
(10 \%)\end{array}$ & $\begin{array}{l}\text { T4 } \\
(15 \%)\end{array}$ & $\begin{array}{l}\text { T5 } \\
(20 \%)\end{array}$ & SEM & LOS \\
\hline \multicolumn{8}{|l|}{ Cut parts } \\
\hline Bled weight ( $\mathrm{g} /$ bird) & 1420.00 & 1355.00 & 1355.00 & 1505.00 & 1355.00 & 55.21 & NS \\
\hline Dressed weight (g/bird) & $1155.00^{\mathrm{c}}$ & $1350.00^{\mathrm{b}}$ & $1350.00^{\mathrm{b}}$ & $1525.00^{\mathrm{a}}$ & $1530.00^{\mathrm{a}}$ & 48.30 & $* * *$ \\
\hline ECW (g/bird) & 1150.00 & 1000.00 & 1075.00 & 1150.00 & 1000.00 & 54.39 & NS \\
\hline Carcass length (cm/bird) & 16.00 & 17.50 & 17.00 & 17.00 & 16.75 & .2363 & NS \\
\hline Breast plate (g/bird) & 375.00 & 275.00 & 325.00 & 400.00 & 300.00 & 21.15 & NS \\
\hline Drum stick (g/bird) & 150.00 & 140.00 & 180.00 & 182.50 & 180.00 & 8.30 & NS \\
\hline Thigh (g/bird) & 163.00 & 180.00 & 163.00 & 195.00 & 200.00 & 8.39 & NS \\
\hline Wings (g/bird) & 126.50 & 425.00 & 112.00 & 126.50 & 160.00 & 57.21 & NS \\
\hline Head (g/bird) & 35.00 & 38.00 & 37.00 & 39.00 & 43.00 & 1.51 & NS \\
\hline Neck (g/bird) & 78.00 & 71.50 & 61.50 & 57.00 & 76.00 & 4.63 & NS \\
\hline Shanks (g/bird) & $59.50^{\mathrm{d}}$ & $100.00^{\mathrm{a}}$ & $67.00^{\mathrm{c}}$ & $85.00^{\mathrm{b}}$ & $60.00^{\mathrm{c}}$ & 5.75 & $* *$ \\
\hline Back (g/bird) & 239.50 & 270.00 & 233.00 & 250.00 & 250.00 & 14.73 & NS \\
\hline \multicolumn{8}{|l|}{ Visceral organs } \\
\hline Heart (g/bird) & 7.00 & 8.00 & 7.00 & 8.00 & 7.50 & 0.45 & NS \\
\hline Liver ( $\mathrm{g} /$ bird) & 25.00 & 26.50 & 24.50 & 26.00 & 14.50 & 1.78 & NS \\
\hline Small intestine $(\mathrm{cm} / \mathrm{bird})$ & 169.75 & 185.00 & 176.50 & 202.50 & 181.50 & 5.08 & NS \\
\hline Large intestine (cm/bird) & 12.00 & 13.50 & 13.50 & 14.50 & 13.75 & 0.37 & NS \\
\hline Full gizzard (g/bird) & 42.00 & 95.00 & 58.00 & 76.50 & 80.00 & 7.20 & NS \\
\hline Kidney (g/bird) & 1.25 & 1.30 & 1.45 & 1.55 & 1.90 & 0.09 & NS \\
\hline
\end{tabular}

Table 9: Effect of graded levels of TNO on haematological indices of broiler finisher birds

\begin{tabular}{llllllll}
\hline & T1 & T2 & T3 & T4 & T5 & & \\
Parameters & $\mathbf{( 0 \% )}$ & $\mathbf{( 5 \% )}$ & $\mathbf{( 1 0 \% )}$ & $\mathbf{( 1 5 \% )}$ & $\mathbf{( 2 0 \% )}$ & SEM & LOS \\
\hline Leukocytes $\left(x 10^{3} / \mu \mathrm{L}\right)$ & 89.50 & 108.50 & 112.00 & 126.50 & 78.50 & 8.36 & NS \\
Erythrocytes $\left(\times 10^{6} / \mu \mathrm{L}\right)$ & 2.91 & 3.25 & 3.18 & 3.22 & 2.87 & 0.11 & NS \\
Packed cell volume $(\%)$ & 29.50 & 30.50 & 32.00 & 32.50 & 29.00 & 1.17 & NS \\
Haemoglobin $(\mathrm{g} / \mathrm{dL})$ & 9.80 & 10.15 & 10.65 & 10.80 & 9.60 & 0.39 & $\mathrm{NS}$ \\
MCV $(\mathrm{fl})$ & 101.50 & 101.75 & 100.70 & 101.40 & 101.00 & 0.16 & $\mathrm{NS}$ \\
MCH $(\mathrm{pg})$ & 33.70 & 33.85 & 33.50 & 33.60 & 33.40 & 0.08 & $\mathrm{NS}$ \\
MCHC $(\mathrm{g} / \mathrm{dL})$ & 33.20 & 33.25 & 33.25 & 33.20 & 33.10 & 0.03 & $\mathrm{NS}$ \\
\hline
\end{tabular}

$\mathrm{NS}=$ Not significantly different at $5 \%(\mathrm{P}<0.05), \mathrm{LOS}=$ Level of significance, $\mathrm{MCV}=$ mean corpuscular volume, $\mathrm{MCH}=$ mean corpuscular haemoglobin, $\mathrm{MCHC}=$ mean corpuscular haemoglobin concentration.

triglycerides ( 0.90 vs. 1.15 vs. 1.10 vs. 1.25 and $1.20 \mathrm{mmol} / \mathrm{L}$ ) increased numerically whereas those of cholesterol, HDLP, LDLP, GOT, GTP and ALP reduced. The values recorded in the present study fell within the normal range for healthy broiler finisher chickens (Jain, 1993). They also agree with the earlier reports of Kwadwo et al. (2014), Agbabiaka et al. (2012) and Agbabiaka et al. (2013). The normal values for serum biochemistry confirm that the birds were not starved, implying that the test ingredient nutritionally adequate for feeding broilers (Alu, 2015a). 


\section{Nutritional value of tiger nut (Cyperus esculentus) offal}

Table 10: Effect of graded levels of TNO on serum biochemical variables of broiler finisher birds

\begin{tabular}{llllllll}
\hline Parameters & T1 & T2 & T3 & T4 & T5 & & \\
\hline Total protein $(\mathrm{g} / \mathrm{dL})$ & 36.00 & 48.00 & 39.50 & 43.50 & 41.50 & 1.69 & $\mathrm{NS}$ \\
Glucose $(\mathrm{mmol} / \mathrm{L})$ & 1.25 & 1.55 & 1.80 & 1.55 & 1.75 & 0.10 & $\mathrm{NS}$ \\
Creatinine $(\mathrm{mmol} / \mathrm{L})$ & 37.50 & 37.00 & 39.50 & 44.00 & 42.50 & 1.21 & $\mathrm{NS}$ \\
Cholesterol $(\mathrm{mmol} / \mathrm{L})$ & 4.80 & 3.35 & 3.80 & 3.20 & 3.85 & 0.28 & NS \\
Triglyceride $(\mathrm{mmol} / \mathrm{L})$ & 0.90 & 1.15 & 1.10 & 1.25 & 1.20 & 0.06 & NS \\
HDLP $(\mathrm{mmol} / \mathrm{L})$ & 0.80 & 0.65 & 0.75 & 0.75 & 0.70 & 0.07 & NS \\
LDLP $(\mathrm{mmol} / \mathrm{L})$ & 0.80 & 0.75 & 0.70 & 0.50 & 0.70 & 0.06 & NS \\
GOT $(\mathrm{i} \mu / \mathrm{L})$ & 272.00 & 207.50 & 207.50 & 319.50 & 282.00 & 20.74 & NS \\
GPT $(\mathrm{i} \mu / \mathrm{L})$ & 125.00 & 151.50 & 69.00 & 80.50 & 108.00 & 11.84 & NS \\
ALP $(\mathrm{i} \mu / \mathrm{L})$ & 446.00 & 335.00 & 413.00 & 453.00 & 361.00 & 25.81 & NS \\
\hline NS $=$ N & & $\mathbf{( 1 0 \% )}$ & SEM
\end{tabular}

$\mathrm{NS}=$ Not significantly different at $5 \%(\mathrm{P}<0.05)$, LOS $=$ Level of significance.

\section{Conclusion}

The study indicated that poultry farmer can use up to $20 \%$ of Tiger nut offal as a replacement for conventional energy source in the diet of broiler chickens without compromising the meat quality and health status of the birds.

\section{Acknowledgement}

My special appreciation goes to TETFund for sponsoring in total, the cost of the research.

\section{References}

Adgidzi, E. A., Imgbian, E. K. and Abu, J. O. 2013. Effects of storage on the quality of Tiger nut (Cyperus esculentus) products. PAT June 2011; 7 (1): 131-147 ISSN: 07945213 online copy available at $w$ w $w$. $p$ a $t$ n sukjournal.net/currentissue

Agbabiaka, L. A., Madubuike, F. N., Ekenyem, B. U. and Esonu, B. O. 2013. Effect of feeding different levels of Tiger nut (Cyperus esculentus L) meal on growth of broiler chicks. American Journal of Experimental Agriculture 3(4): $996-1004, \quad 2013$ SCIENCEDOMAIN international www.science domain. org
Agbabiaka, L. A., Madubuiko, C. U. and Anyanwu, C. N. 2012 . Replacement value of tiger nut meal (Cyperus esculentus) with Maize in catfish (Clarias gariepinus) diets. Science Research Reporter 2(2):130-134

Aletor, M., Venus, A. and Adeogun, O. A. 1995. Food Chemistry. Journal of food Science 53:475-477.

Alu, S. E. 2015a. Response of weaner rabbits fed graded levels of Tiger nut (Cyperus esculentus) offal based diets. FULafia Journal of Science and Technology, vol. 1 No. 1 Pp. 31-36.

Alu, S. E. 2015b. Primer of Animal Nutrition and Biochemistry. First edition, ISBN: 978-478483-1, 255P, Onaivi Printing and Publishing Company, LTD, Nigeria.

Alu, S. E., Ruma, R. S., Umbugadu, A. A. U. and Makinde, O. J. 2009. Effects of different dietary fibre sources on the growth performance and carcass characteristics of growing rabbits. $14^{\text {th }}$ Annual Conference Animal Science Association of Nigeria. (Ladoke Akintola University of Technology, Ogbomoso, Oyo 


\section{Alu, Oseze and Ogoshi}

State, Nigeria). Pp.390-392.

AOAC (Association of Official Analytical Chemists) 2000 . Official methods of analysis of the association of official analytical chemists: Food composition; additives; natural contaminants. William, H. (eds.). Volume II, $17^{\text {th }}$ edition. Washington, D.C. Official method 982.14.

Bamishaiye, E., Muhammad, N. O. and Bamishaiye, O. M. 2010. Haematological parameters of albino rats fed on tiger nut (Cyperus esculentus) tuber oil meal- based diet. Interl. J. Nutr. Wellness. (2010). Vol. 10, Num.1, DOI: $10.5580 / 187 b$.

Belewu, M. A. and Adedunni, A. O. 2008. Preparation of Kunu from exploited rich food source tiger-nut (Cyperus esculentus). Pakistan Journal of Nutrition, 7:109-111.

Bibek, R. 2001. Fundamental Food Microbiology $\left(2^{\text {nd }}\right.$ ed.) The C.R.C Press Ltd Washington D. C. pp 56 90.

Grosso, J. L. B. M., Balieiro, J. C. C., Eler, J. P., Ferraz, J. B. S., Mattos, E. C., Filho Michelan, T., Feicio, A. M. and Rezende, F. M. 2009. Estimates of genetic trend for carcass traits in a commercial line. Genetic and Molecular Research 8, 97-104.

Ikani, E. I. and Adesehinwa, A. O. K. 2000. Promoting non-conventional feed stuffs in livestock feeding. The need for extension strategy. In: Animal Production in the new millennium: challenges and option.

Jain, C. N. 1986. Schalms Veterinary Ha ematology. $4^{\text {th }}$ edition, Philadephia. Lea and Febiger Publishers. Pp 564-575.
Kelly, W. R. 1979. Veterinary Clinical Diagnosis. $2^{\text {nd }}$ edition, London. B a illiere Tind a l l publishers.Pp 47-56.

Kleczek, K., Wilkiewicz-Wawro, E., Wawro, J. and Makowski, W. 2007. Effect of body weights of day-old Muscovy ducklings on the growth and carcass traits. Arch. Tier. Dumm-merstorf, 2, 204-213.

Kwadwo, O., Atuahene, C. C., AttohKotoku, V. and Adjei, M. B. 2014. The growth performance, carcass and haematological characteristics of broiler chickens fed alkaline-treated Tiger nut (Cyperus Esculentus) residue meal. J. Anim. Sci. Adv. 2014, 4( 10$): 1068-1081$ DOI : $10.5455 /$ jasa.20140928032536.

Margi, S. 1997. Veterinary clinical $1 \mathrm{aboratory}$ procedures Pp151.published by Mosby publishing excellent, USA.

McDonald, P., Edwards, R. A. and Greenhalgh, J. F. D. 1995. Animal nutrition. Fifth edition. Longman Publ. Pp. 221-235.

Mohammed, M. A., Hassan, H. M. A. and EL-Barkouky, E. M. A. 2008. E f e c t of $m$ a $n n$ a $n$ oligosaccharide on performance and carcass characteristics of broiler chicks. Journal of Agriculture and Social Sciences, 4, 13-17.

NIMET 2008. Nigerian Meteorological Agency, Lafia, Nasarawa State.

Oladele, A. K., Alatise, P. S. and Ogundele, O. 2010. Evaluation of tiger nut (Cyperus esculentus) meal as a replacement for maize meal in the diet of catfish (Clarias gariepinus) fingerlings. World $J$. Agr. Sci., 6(1): 18-22 (2010).

Oladele, O. and Aina, T. O. 2007. Analysis 
Nutritional value of tiger nut (Cyperus esculentus) offal

of edible crops. Journal of Agricultural science. 6:21-24.

Oluyemi, J. A. and Robert, F. A. 2002. Poultry Production in warm wet climates, $2^{\text {nd }}$ edition, published by Macmillan publishers limited, London Pp.45 -77.

Pauzenga, U. 1985. Feeding Parent Stock. Zoo technical international. Pp. 2224.

Sanchez-Zapata, E., Fernandez-Lopez, J. and Perez-Alvarez, J. A. 2012. T i g e r n u t ( C y p e r u s esculentus), commercialization: Health aspects, composition, p roperties and food applications. Compr. Res. Food Sci. Saf., vol. 11, (2012).
Schalm, O. W., Jain, N. C. and Caroll, E. J. 1975. Textbook of Veterinary Haematology, $2^{\text {nd }} \quad$ Edition, Published by Lea and Febiger, Philadelphia, Pp. 129-250.

Steel, R. G. and Torrie, J. H. 1980. Principles and procedures of statistics. New York McGraw-Hill. Pages 137-269.

Yakubu, A., Ayoade, J. A. and Dairu, M. 2010. Effect of genotype and population density on growth performance, carcass characteristic and cost-benefits of broiler chickens in north central Nigeria. Tropical Animal Health Production (2010) 42:719-727.

Received: $17^{\text {th }}$ September, 2019 Accepted: $27^{\text {th }}$ January, 2020 